\title{
Interrelationships between riboflavin and dietary energy and protein utilization in growing chicks
}

\author{
By S. T. CHOU,* J. L. SELL, $\uparrow$ AND P. A. KONDRA \\ Department of Animal Science, University of Manitoba, \\ Winnipeg, Manitoba, Canada
}

(Received I9 Fune 1970-Accepted 2 Fune 1971)

\begin{abstract}
I. Reduced intake of energy or protein per se decreased riboflavin requirement of the chicks under restricted feeding regimens.

2. In severe riboflavin deficiency $(2.26 \mathrm{mg} / \mathrm{kg} \mathrm{diet})$, efficiency of utilization of both energy and protein was decreased significantly under ad lib. conditions of feeding.

3. Efficiency of utilization of energy (but not protein) was decreased significantly in borderline riboflavin deficiency $(3.02 \mathrm{mg} / \mathrm{kg}$ diet $)$, when chicks were fed ad lib.

4. Efficiency of protein utilization was decreased significantly in severe riboflavin deficiency when chicks received an energy-restricted diet supplying 80,70 or $60 \%$ of the energy intake of the controls.

5. Neither energy nor protein utilization was affected by riboflavin deficiency when both energy and protein were restricted to $70 \%$ of that consumed by chicks fed ad lib. However, the riboflavin deficiency produced characteristic deficiency symptoms, namely heterophilia, curled-toe paralysis, and reduction in concentration of liver riboflavin.
\end{abstract}

During the past three decades numerous studies have been conducted on the requirement for riboflavin in relation to dietary energy or protein. Several workers (Mannering, Lipton \& Elvehjem, I94I ; Reiser \& Pearson, 1949; Appelgate \& Potter, 1963; Chu, Potter, Appelgate \& Leighton, 1964) found that dietary energy governed the riboflavin requirement, whereas others (Sarett, Klein \& Perlzweig, 1942; Sarett \& Perlzweig, 1943; Oldham, Lounds \& Porter, 1947; Kaunitz, Wiesinger, Blodi, Johnson \& Slanetz, I954) reported that dietary protein determined the requirement. These two views appear to have arisen because of differences in the experimental conditions used by various investigators. The present series of experiments was designed to study: (a) the effect of dietary energy or protein per se on riboflavin requirement of chicks; $(b)$ the effects of riboflavin intake upon efficiency of energy and protein utilization by chicks on restricted feeding regimens, using carcass analysis; (c) the sensitivities of various criteria to riboflavin deficiency.

\section{EXPERIMENTAL}

Day-old commercially available broiler cockerels were used in both trials. The chicks were placed in electric battery brooders with raised wire-mesh floors and thermostatically controlled heating units. The initial brooding temperature was $35^{\circ}$ and it

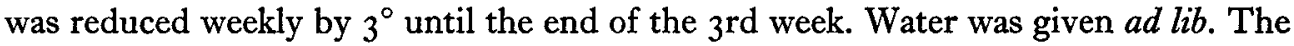

* Present address: Department of Biomedical Sciences, Ontario Veterinary College, University of Guelph, Guelph, Ontario, Canada.

+ Present address: Animal Science Department, North Dakota State University, Fargo, North Dakota, USA. 
water troughs were cleaned at least once every $3 \mathrm{~d}$. Light was provided continuously. The compositions of the diets are shown in Table 1 . Two feeding trials ( $I$ and 2 ) were conducted with a total of 465 chicks.

Table I. Composition of diets and proportions in which they were given to the different experimental groups

\begin{tabular}{|c|c|c|c|c|c|c|}
\hline & \multicolumn{3}{|c|}{ Trial I } & \multicolumn{3}{|c|}{ Trial 2} \\
\hline & $\mathrm{E}_{\mathrm{I}}$ & $\mathrm{E}_{2}$ & $\mathrm{E}_{3}$ & $P_{\mathbf{I}}$ & $\mathrm{P}_{2}$ & $P_{3}$ \\
\hline Dextrose & $14 \cdot 0$ & $9 \cdot 0$ & $3 \cdot 9$ & $6 \cdot 45$ & $6 \cdot 45$ & $6 \cdot 45$ \\
\hline Sucrose & 14.0 & $9 \cdot 0$ & 3.9 & $6 \cdot 45$ & $6 \cdot 45$ & $6 \cdot 45$ \\
\hline Maize starch & $24{ }^{\circ} \circ$ & $15 \cdot 3$ & 6.7 & II $\cdot 00$ & II $\cdot 00$ & II $\cdot 00$ \\
\hline Soya-bean protein & $27 \cdot 0$ & 27.00 & $27 \cdot 00$ & $27 \cdot 00$ & $22 \cdot 95$ & 18.90 \\
\hline Glycine & 0.22 & 0.22 & 0.22 & 0.22 & 0.19 & 0.15 \\
\hline Methionine & 0.78 & 0.78 & 0.78 & 0.78 & 0.66 & 0.55 \\
\hline Soya-bean oil & $I \cdot 0$ & $I \cdot 0$ & $x \cdot 0$ & $\mathrm{I} \cdot 0$ & $\mathrm{x} \cdot \mathrm{O}$ & $I \cdot 0$ \\
\hline Lard & $10 \cdot 0$ & $10 \cdot 0$ & $10 \cdot 0$ & $10 \cdot 0$ & 10.0 & 10.0 \\
\hline Vitamin premix* & $I \cdot 0$ & $\mathbf{I} \cdot 0$ & $I \cdot O$ & $I \cdot 0$ & $1 \cdot 0$ & I. 0 \\
\hline Mineral premix $\dagger$ & 6.0 & $6 \cdot 0$ & $6 \cdot 0$ & $6 \cdot 0$ & $6 \cdot 0$ & $6 \cdot 0$ \\
\hline Cellulose (alphacel) & $2 \cdot 0$ & $2 \cdot 0$ & $2 \cdot 0$ & $2 \cdot 0$ & $2 \cdot 0$ & $2 \cdot 0$ \\
\hline Total weight (g) & $100 \cdot 0$ & $81 \cdot 3$ & $62 \cdot 5$ & $7 x \cdot 9$ & $67 \cdot 7$ & $63 \cdot 5$ \\
\hline $\begin{array}{l}\text { Metabolizable energy } \\
\text { content (kcal) }\end{array}$ & $334 \cdot 0$ & $267 \cdot 2$ & $200 \cdot 4$ & $233 \cdot 8$ & $233 \cdot 8$ & 233.8 \\
\hline $\begin{array}{l}\text { Relative metabolizable } \\
\text { energy content }\end{array}$ & 100 & 80 & 60 & 70 & 70 & 70 \\
\hline Protein content $(\mathrm{g})$ & 28 & 28 & 28 & $28 \cdot 0$ & $23 \cdot 8$ & $19 \cdot 6$ \\
\hline Relative protein content & 100 & 100 & 100 & 100 & 85 & 70 \\
\hline
\end{tabular}

* Supplied: (mg/loog diet) pteroylmonoglutamic acid 0.2 , biotin 0.02 , calcium pantothenate 2 , myoinositol 10o, pyridoxol hydrochloride 0.6 , menaphthone 0.1 , thiamin hydrochloride 0.4 , nicotinic acid 8 , cyanocobalamin 0.002, p-aminobenzoic acid 4, choline 200, ascorbic acid 22, Santoquin (6-ethoxyl-1,2dihydro-2,2,4-trimethylquinoline; Monsanto Co., St Louis, Missouri) 30.53, and (i.u./roo g diet) retinol I000, $\alpha$-tocopheryl acetate I 5 , cholecalciferol 200.

$\dagger$ Supplied (g/100 g diet): defluorinated phosphate $3.5, \mathrm{MnSO}_{4} \cdot 4 \mathrm{H}_{2} \mathrm{O}$ 0. $\mathrm{I}, \mathrm{ZnSO}_{4} \cdot 7 \mathrm{H}_{2} \mathrm{O} 0.024$, $\mathrm{CuSO}_{4} \cdot \mathrm{H}_{2} \mathrm{O} 0.002, \mathrm{CoCl}_{2} .6 \mathrm{H}_{2} \mathrm{O} 0.00015, \mathrm{FeSO}_{4}$ (anhydrous) $0.006, \mathrm{KCl} 0.3, \mathrm{~K}_{2} \mathrm{CO}_{3} 0.2, \mathrm{KI} 0.002$, $\mathrm{MgSO}_{4} \cdot 7 \mathrm{H}_{2} \mathrm{O} 0.5, \mathrm{NaCl} 0.5, \mathrm{H}_{3} \mathrm{BO}_{3} 0.0009, \mathrm{KAl}\left(\mathrm{SO}_{4}\right)_{2} .12 \mathrm{H}_{2} \mathrm{O} 0.00094, \mathrm{Na}_{2} \mathrm{MoO}_{4} \cdot 2 \mathrm{H}_{2} \mathrm{O} 0.0001 \mathrm{I}$, $\mathrm{Mg}_{2} \mathrm{Si}_{3} \mathrm{O}_{8} \cdot 5 \mathrm{H}_{2} \mathrm{O} 0 \cdot 75, \mathrm{Al}(\mathrm{OH})_{3} \cdot \mathrm{nH}_{2} \mathrm{O} 0 \cdot 25$.

\section{Trial $\mathrm{x}$. The effect of restricting energy intake to varying extents while maintaining protein intake at the control level}

Fifteen dietary treatments were used, involving three levels of intake of metabolizable energy and five of riboflavin, arranged factorially (Table 2). Each diet was given to three replicate pens of five chicks each. High-energy diets (metabolizable energy content, $3340 \mathrm{kcal} / \mathrm{kg}$ ) were offered $a d l i b$. and designated $\mathrm{E}_{\mathrm{r}}$. The five dietary intakes of riboflavin were designated $\mathrm{R}_{\mathrm{I}}-\mathrm{R}_{5}$ (Table 2 ), and individual diets were named by combining their energy and riboflavin symbols, e.g. EI-R3. Diet $E_{I}-R_{1}$, containing an adequate amount of riboflavin was used as a control, and the average daily feed intake of the three pens of chicks given this diet was used to calculate the amounts of feed to be given to the restricted groups. Medium and low energy intakes were achieved by reducing the amounts of dextrose, sucrose, and starch in the diets and by giving them in restricted amounts once daily. Group $\mathrm{E}_{2}$ received $80 \%$ and group $\mathrm{E}_{3} 60 \%$, respectively, of the metabolizable energy intake of the control groups (Table I). All groups of chicks therefore consumed approximately the same amounts of protein, 
minerals, fibre and vitamins (with the exception of riboflavin). Thus, the differences between energy treatments were in metabolizable energy intake only, and the differences between treatments within each energy level were in riboflavin intake only.

Pooled body-weights were recorded every $4 \mathrm{~d}$. At the end of the $16 \mathrm{~d}$ feeding period three chicks (selected at random) from each pen of the selected treatments were killed, and the carcasses were analysed to determine gains in protein, fat and ash by the method described by Carew \& Hill (1964).

Table 2. Riboflavin content of diets $(\mathrm{mg} / \mathrm{kg})$

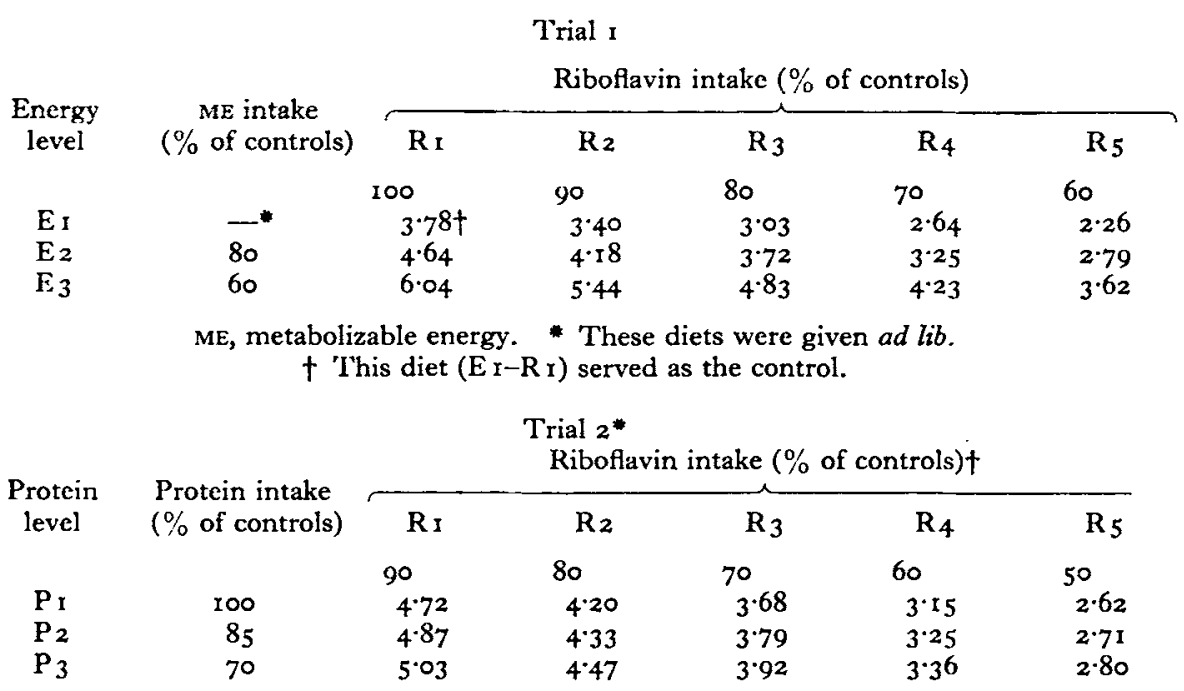

- Metabolizable energy intake of all treatment groups was $70 \%$ of controls.

+ The diet $\mathrm{E}_{\mathrm{I}-\mathrm{R}} \mathrm{I}$ as shown in trial $\mathrm{x}$ served as the control, given ad lib. to an additional three groups of chicks.

Liver samples from three chicks from each experimental pen were frozen and subsequently analysed for moisture, protein, ether extractives, ash and riboflavin. Riboflavin contents of liver and feed samples were determined by microbiological assays (Association of Official Agricultural Chemists, 1960).

\section{Trial 2. The effect of restricting energy intake to $70 \%$ of the control intake while restricting protein intake to varying extents}

Fifteen dietary treatments were used, involving three levels of protein intake and five of riboflavin, arranged factorially (Table 2). Each diet was given to three replicate pens each of five chicks. Diet $E_{I}-R_{I}$, the control diet used in trial I, served as a control and was offered $a d$ lib. to an additional three groups of chicks. The average feed intake of the control chicks was used to calculate the daily rations for chicks on the other treatments. The metabolizable energy intake of all experimental groups was restricted to $70 \%$ of that consumed by the control chicks by the method used in trial I. Protein intakes were 100,85 , or $70 \%$ of that of the control chicks. This was achieved by reducing the amounts of soya-bean protein given (i.e. the technique used 
in energy restriction for trial I was used in protein restriction for trial 2) (Table I). Once again, the intakes of minerals, vitamins (except for riboflavin) and fibre were the same for all treatments. Thus, the differences between the protein treatments were in protein intake only, and the differences between treatments within each protein level were in riboflavin intake only. Other experimental procedures were the same as in trial I, except that at the end of the feeding period random samples of three chicks from each pen were bled from the brachial veins into heparinized capillary tubes for haematocrit determination. From the same bleeding, blood smears were prepared using Giemsa stain for making differential counts of leucocytes.

All results were analysed by the method of analysis of variance (Snedecor, 1956) and the treatment means were compared by Duncan's multiple range test (Duncan, 1955). Trials $I$ and 2 were each treated as three subtrials according to the level of energy or protein intake for this analysis. A percentage incidence of curled-toe paralysis was subtracted from 100 before an angular transformation (Steel \& Torrie, 1960) was made followed by an analysis of variance and multiple range test.

Table 3. Trial $\mathrm{I}$ : effect on feed intake, body-weight gain and incidence of curled-toe paralysis $(C T P)$ of restricting energy intake of the chicks to varying extents while maintaining protein intake at the control level

(Mean values for fifteen chicks/treatment)

\begin{tabular}{|c|c|c|c|c|c|c|}
\hline Diet & $\begin{array}{c}\text { ME } \\
\text { intake } \\
(\% \text { of control })\end{array}$ & $\begin{array}{l}\text { Riboflavin } \\
\text { intake } \\
\text { (\% of control) }\end{array}$ & $\begin{array}{c}\text { Feed } \\
\text { intake } \\
\text { (g/chick) }\end{array}$ & $\begin{array}{c}\text { Body-wt } \\
\text { gain } \\
\text { (g/chick) }\end{array}$ & \multicolumn{2}{|c|}{$\begin{array}{c}\text { Incidence } \\
\text { of CTP } \\
\text { (15 chicks) }\end{array}$} \\
\hline$E_{I}-R_{I}$ & 100 & 100 & $33 \mathrm{I}$ & 189 & & 0 \\
\hline $\mathrm{E}_{1}-\mathrm{R}_{2}$ & 99 & 89 & 327 & 182 & & I \\
\hline$E_{I}-R_{3}$ & 95 & 76 & 315 & 174 & & $2^{*}$ \\
\hline $\mathrm{E}_{\mathrm{I}}-\mathrm{R}_{4}$ & 94 & 65 & 310 & 168 & & $3^{*}$ \\
\hline \multirow[t]{2}{*}{$E_{I}-R_{5}$} & 76 & 45 & 250 & 120 & & $10 * *$ \\
\hline & & & SE $7 \cdot 7$ & $28 \cdot 9$ & Total & I6 \\
\hline \multirow{6}{*}{$\left.\begin{array}{l}\mathrm{E}_{2}-\mathrm{R}_{1} \\
\mathrm{E}_{2}-\mathrm{R}_{2} \\
\mathrm{E}_{2}-\mathrm{R}_{3} \\
\mathrm{E}_{2}-\mathrm{R}_{4} \\
\mathrm{E}_{2}-\mathrm{R}_{5}\end{array}\right\}$} & & 100 & 217 & 147 & & 0 \\
\hline & & 90 & 235 & $\times 66$ & & 0 \\
\hline & 80 & 80 & 209 & 147 & & 0 \\
\hline & & 70 & 214 & I 47 & & $\mathbf{I}$ \\
\hline & & 60 & 216 & 140 & & $9^{* *}$ \\
\hline & & & $S E 4 \cdot 6$ & $4^{\cdot r}$ & Total & 10 \\
\hline \multirow{6}{*}{$\left.\begin{array}{l}\mathrm{E}_{3}-\mathrm{R}_{1} \\
\mathrm{E}_{3}-\mathrm{R}_{2} \\
\mathrm{E}_{3}-\mathrm{R}_{3} \\
\mathrm{E}_{3}-\mathrm{R}_{4} \\
\mathrm{E}_{3}-\mathrm{R}_{5}\end{array}\right\}$} & & 100 & 185 & ${ }_{13} 8$ & & 0 \\
\hline & & 90 & I92 & 149 & & 0 \\
\hline & 60 & 80 & I92 & I 48 & & 0 \\
\hline & & 70 & I9I & I47 & & $\mathbf{I}$ \\
\hline & & 60 & I 76 & 125 & & $9^{* *}$ \\
\hline & & & SE $5 \cdot \mathrm{I}$ & $5 \cdot 8$ & Total & ro \\
\hline
\end{tabular}

ME, metabolizable energy; SE, standard error.

SE $5 \cdot 1$

5.8 Total ro

** or * indicates the value is significantly different $(P<0.01$ or $<0.05$, respectively $)$ from the value for the corresponding group with the highest riboflavin intake within each energy level. 


\section{RESULTS}

\section{Effect of dietary energy and protein on riboflavin requirement}

When energy intake alone was restricted to 80 or $60 \%$ of that of the control chicks, the chicks required only $70 \%$ of the riboflavin for maximum body-weight gain and $80 \%$ for the prevention of curled-toe paralysis (Table 3 ).

Table 4. Trial 2: effect on feed intake, body-weight gain and incidence of curled-toe paralysis $(C T P)$ of restricting energy intake of the chicks to $70 \%$ of the control intake while restricting protein intake to varying extents

(Mean values for fifteen chicks/treatment)

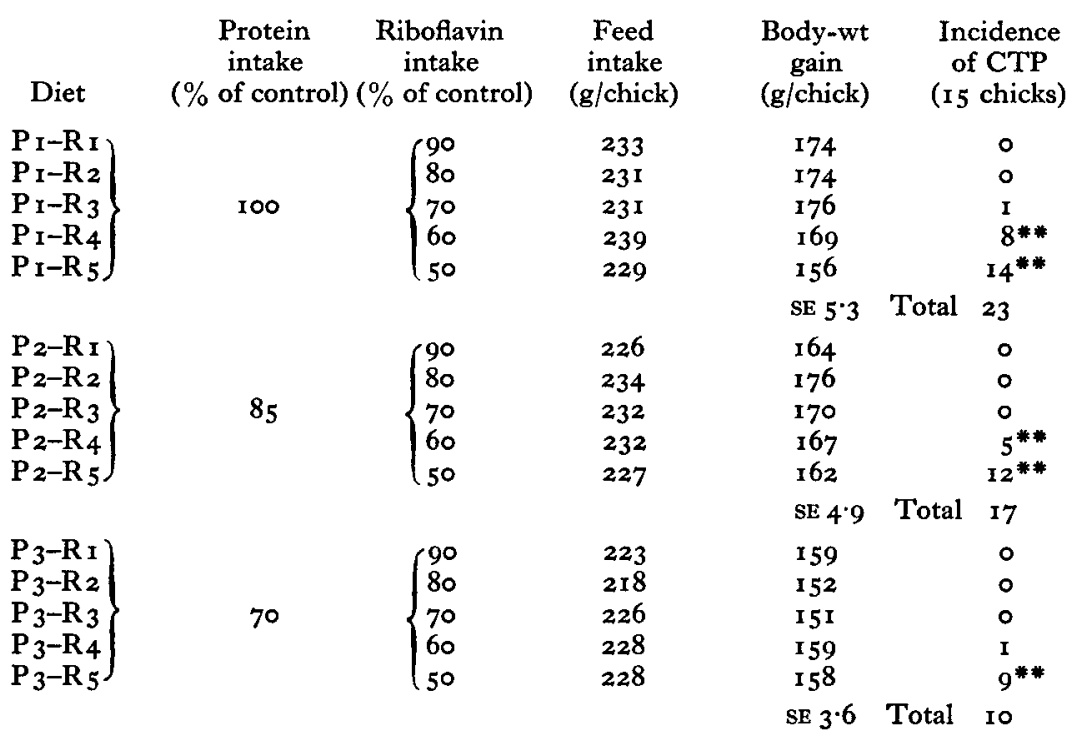

SE, standard error.

** indicates the value is significantly different $(P<0.01)$ from the values for the other groups.

Reduced protein intake per se resulted in a slight reduction in the riboflavin requirement of the chicks for growth (Table 4). Reduction in riboflavin requirement ran parallel to the amount of protein consumed when the incidence of curled-toe paralysis was used as a criterion of riboflavin adequacy.

When the chicks were given diets with energy restricted to $70 \%$ of that of the control group, the riboflavin requirement for the prevention of curled-toe paralysis was reduced to $70 \%$ of the control for both protein-restricted treatments, as shown by chicks fed on diets $\mathrm{P}_{2}-\mathrm{R}_{1}$ to $\mathrm{P}_{2}-\mathrm{R}_{5}$ and $\mathrm{P}_{3}-\mathrm{R}_{1}$ to $\mathrm{P}_{3}-\mathrm{R}_{5}$ (Table 4 ).

Many of the groups of chicks fed on the riboflavin-deficient diets $\left(\mathrm{E}_{2}-\mathrm{R}_{5}, \mathrm{P}_{\mathrm{I}}-\mathrm{R}_{4}\right.$, $\mathrm{P}_{1}-\mathrm{R}_{5}, \mathrm{P}_{2}-\mathrm{R}_{4}, \mathrm{P}_{2}-\mathrm{R}_{5}$ and $\mathrm{P}_{3}-\mathrm{R}_{5}$ ) had body-weight gains very similar to those of the chicks on the same dietary level of energy or protein receiving more dietary riboflavin, yet they had a significantly $(P<0.01)$ higher incidence of curled-toe paralysis. These results illustrate that the riboflavin requirement of the chicks for maximum growth was less than the requirement for prevention of curled-toe paralysis. 


\section{Efficiency of dietary energy and protein utilization as influenced by dietary riboflavin intake}

In severe riboflavin deficiency (i.e. in chicks given diet $\mathrm{E}_{\mathrm{I}}-\mathrm{R}_{5}$ containing $2 \cdot 26 \mathrm{mg}$ riboflavin $/ \mathrm{kg}$ diet) retention (percentage of dietary energy or protein recovered in carcass) of both energy and protein was lower than that of chicks given diet E I-R I, adequate in riboflavin (Table 5 ).

Table 5. Trial $\mathrm{I}$ : efficiency of utilization of dietary energy and protein by the chicks, as influenced by dietary riboflavin level

(Mean values for nine chicks/treatment)

\begin{tabular}{|c|c|c|c|c|c|}
\hline Diet & $\begin{array}{l}\text { Dietary } \\
\text { riboflavin } \\
(\mathrm{mg} / \mathrm{kg})\end{array}$ & $\begin{array}{c}\text { Energy } \\
\text { intake } \\
\text { (kcal/chick) }\end{array}$ & $\begin{array}{l}\text { Energy } \\
\text { retention } \\
(\%)\end{array}$ & $\begin{array}{c}\text { Protein } \\
\text { intake } \\
\text { (g/chick) }\end{array}$ & $\begin{array}{c}\text { Protein } \\
\text { retention } \\
(\%)\end{array}$ \\
\hline $\begin{array}{l}E_{I}-R_{I} \\
E_{I}-R_{3} \\
E_{I}-R_{5}\end{array}$ & $\begin{array}{l}3.78 \\
3.02 \\
2.26\end{array}$ & $\begin{array}{l}895 \\
849 \\
674^{* *}\end{array}$ & $\begin{array}{l}29 \cdot 9 \\
23 \cdot 6 * * \\
21 \cdot 5 * *\end{array}$ & $\begin{array}{l}8 I \cdot 4 \\
77 \cdot 3 \\
6 I \cdot 4 *\end{array}$ & $\begin{array}{l}44 \cdot 6 \\
45^{\cdot} 4 \\
38 \cdot 9^{*}\end{array}$ \\
\hline & & SE $4 \cdot 8$ & 0.9 & $2 \cdot 7$ & $2 \cdot I$ \\
\hline
\end{tabular}

$\mathrm{SE}$, standard error.

** or * indicates the value is significantly different $(P<0.0 \mathrm{r}$ or $<0.05$, respectively) from the corresponding value for $\mathrm{E} r-\mathrm{R} r$.

Table 6. Trials I and 2: efficiency of utilization of dietary energy and protein by the energy-restricted chicks as influenced by dietary riboflavin level

(Mean values for nine chicks/treatment)

\begin{tabular}{|c|c|c|c|c|}
\hline Diet & $\begin{array}{c}\text { ME intake } \\
(\% \text { of control) }\end{array}$ & $\begin{array}{l}\text { Riboflavin } \\
\text { intake } \\
\text { (\% of control) }\end{array}$ & $\begin{array}{c}\text { Energy } \\
\text { retention } \\
(\%)\end{array}$ & $\begin{array}{l}\text { Protein } \\
\text { retention } \\
(\%)\end{array}$ \\
\hline \multirow[t]{2}{*}{$\left.\begin{array}{l}E_{2}-R_{r} \\
E_{2}-R_{3} \\
E_{2}-R_{5}\end{array}\right\}$} & \multirow[t]{2}{*}{80} & \multirow[t]{2}{*}{$\begin{array}{r}100 \\
80 \\
60\end{array}$} & $\begin{array}{l}20 \cdot 2 \\
I 8 \cdot 4 \\
24 \cdot I\end{array}$ & $\begin{array}{l}48 \cdot 8 \\
50 \cdot 5 \\
45 \cdot 7^{*}\end{array}$ \\
\hline & & & SE $\quad I \cdot 69$ & $0.3 \mathrm{I}$ \\
\hline \multirow[t]{2}{*}{$\left.\begin{array}{l}P_{I}-R_{I} \\
P_{I}-R_{3} \\
P_{I}-R_{5}\end{array}\right\}$} & \multirow[t]{2}{*}{70} & \multirow[t]{2}{*}{$\begin{array}{l}90 \\
70 \\
50\end{array}$} & $\begin{array}{l}18 \cdot 0 \\
17 \cdot 6 \\
19 \cdot 8\end{array}$ & $\begin{array}{l}49 \cdot 0 \\
50^{\circ} 0 \\
45^{\circ} 6^{*}\end{array}$ \\
\hline & & & SE $\quad 0.89$ & 0.08 \\
\hline \multirow[t]{2}{*}{$\left.\begin{array}{l}\mathrm{E}_{3}-\mathrm{R}_{1} \\
\mathrm{E}_{3}-\mathrm{R}_{3} \\
\mathrm{E}_{3}-\mathrm{R}_{5}\end{array}\right\}$} & \multirow[t]{2}{*}{60} & \multirow[t]{2}{*}{$\begin{array}{r}100 \\
80 \\
60\end{array}$} & $\begin{array}{l}\text { I } 4.1 \\
\text { I3.9 } \\
\text { I } 3.8\end{array}$ & $\begin{array}{l}43 \cdot 7 \\
44 \cdot 2 \\
40^{\circ} \cdot 8^{*}\end{array}$ \\
\hline & & & SE $\quad 0.08$ & 0.46 \\
\hline
\end{tabular}

ME, metabolizable energy; SE, standard error.

* Value significantly different $(P<0.05)$ from that for the other groups within each energy level.

The chicks given diets $E_{I}-R_{3}$ (slightly deficient in riboflavin) and $E_{I}-R_{I}$ (adequate in riboflavin) consumed similar amounts of energy and protein; whereas the percentage retention of energy in carcass as fat was significantly different $(P<0.01)$, namely 23.6 and $29.9 \%$ respectively, the percentage retention of protein was similar for both diets (Table 5). These results show that, when the diet was not severely deficient 
in riboflavin, fat deposition alone was reduced while the efficiency of protein utilization was not affected.

Efficiency of protein utilization was significantly decreased $(P<0.05)$ by severe riboflavin deficiency (groups $\mathrm{E}_{2}-\mathrm{R}_{5}, \mathrm{P}_{\mathrm{I}}-\mathrm{R}_{5}$, and $\mathrm{E}_{3}-\mathrm{R}_{5}$ ) when energy intake was restricted to 80,70 or $60 \%$ of that of the control chicks while keeping protein intake at the control level (Table 6). However, retention of energy by the same chicks was not significantly affected by riboflavin deficiency.

Table 7. Trial 2: efficiency of utilization of dietary energy and protein by the energyand protein-restricted chicks as influenced by dietary riboflavin level

(Mean values for nine chicks/treatment)

\begin{tabular}{|c|c|c|c|c|}
\hline Diet & $\begin{array}{cc}\text { ME } & \text { Protein } \\
\text { intake } & \text { intake } \\
(\% \text { of control })(\% \text { of control })\end{array}$ & $\begin{array}{l}\text { Riboflavin } \\
\text { intake } \\
\text { (\% of control) }\end{array}$ & $\begin{array}{l}\text { Energy } \\
\text { retention } \\
(\%)\end{array}$ & $\begin{array}{l}\text { Protein } \\
\text { retention } \\
(\%)\end{array}$ \\
\hline $\left.\begin{array}{l}P_{2}-R_{1} \\
P_{2}-R_{3} \\
P_{2}-R_{5}\end{array}\right\}$ & 85 & $\left\{\begin{array}{l}90 \\
70 \\
50\end{array}\right.$ & $\begin{array}{l}17 \cdot 1 \\
21 \cdot 1 \\
19 \cdot 5\end{array}$ & $\begin{array}{l}52 \cdot 2 \\
53 \cdot 3 \\
54 \cdot 4\end{array}$ \\
\hline $\begin{array}{l}\mathrm{P}_{3}-\mathrm{R}_{\mathbf{1}} \\
\mathrm{P}_{3}-\mathrm{R}_{3} \\
\mathrm{P}_{3}-\mathrm{R}_{5}\end{array}$ & 70 & $\left\{\begin{array}{l}90 \\
70 \\
50\end{array}\right.$ & $\begin{array}{l}\text { SE I.4I } \\
22 \cdot 0 \\
\text { I } 5.9 \\
23.9\end{array}$ & $\begin{array}{l}0.95 \\
6 r \cdot 3 \\
56 \cdot 8 \\
59 \cdot 6\end{array}$ \\
\hline
\end{tabular}

ME, metabolizable energy; SE, standard error.

Neither energy nor protein retention was decreased by a borderline deficiency of riboflavin in chicks restricted in both energy and protein intakes, e.g. chicks given riboflavin-deficient diets $\left(\mathrm{P}_{2}-\mathrm{R}_{5}\right.$ and $\mathrm{P}_{3}-\mathrm{R}_{5}$, Table 7$)$ appeared to utilize both dietary energy and protein efficiently even though a majority of the chicks given these diets suffered from curled-toe paralysis. This indicates that, when the riboflavin deficiency was borderline, certain metabolic disturbances induced curled-toe paralysis without appreciably affecting the retention of dietary energy or protein in the carcasses of the chicks.

\section{Biochemical and haematological studies}

Effect of dietary riboflavin on liver riboflavin content. Results of the microbiological assay for riboflavin content of the livers are shown in Tables 8 and 9 for trials $I$ and 2 respectively. There was no significant difference between the determined and the calculated riboflavin contents of the diets.

The results for trials $I$ and 2 were analysed by pooling the results for the three subtrials in order to test for main effects and interactions by analyses of variance. It was found that the restriction of either energy or riboflavin intake had a significant effect $(P<0.05)$ on concentration of riboflavin in the livers, i.e. an increase for energy restriction and a decrease for riboflavin restriction. However, the effects of energy and riboflavin intakes were independent of each other, as indicated by a non-significant interaction. Similarly, restriction of protein or riboflavin intake per se also had a significant effect $(P<0.05)$ on the concentration of liver riboflavin, namely an 
increase for protein restriction and again a decrease for riboflavin restriction. However, riboflavin requirement was not affected by the level of protein intake.

Heterophilia. Percentage heterophil counts increased markedly as a result of riboflavin deficiency (Table 9). When the results of percentage heterophil counts for the chicks given riboflavin-deficient diets producing a high incidence of curled-toe

Table 8. Trial $\mathrm{I}$ : effect of riboflavin intake on liver riboflavin content in chicks

(Mean values for nine chicks/treatment)

\begin{tabular}{|c|c|c|c|c|}
\hline Diet & $\begin{array}{c}\text { ME intake } \\
(\% \text { of control })\end{array}$ & $\begin{array}{l}\text { Riboflavin } \\
\text { content of } \\
\text { diet }(\mathrm{mg} / \mathrm{kg})\end{array}$ & $\begin{array}{l}\text { Liver riboflavin } \\
\text { ( } \mu \mathrm{g} / \mathrm{g} \text { fresh liver })\end{array}$ & $\begin{array}{c}\text { Liver wt } \\
(\% \text { of body-wt) }\end{array}$ \\
\hline $\begin{array}{l}E_{I}-R_{I} \\
E_{I}-R_{2} \\
E_{I}-R_{3} \\
E_{I}-R_{4} \\
E_{I}-R_{5}\end{array}$ & $\begin{array}{r}100 \\
99 \\
95 \\
94 \\
76\end{array}$ & $\begin{array}{l}3.71 \\
3.40 \\
3.05 \\
2 \cdot 78 \\
2 \cdot 75\end{array}$ & $\begin{array}{l}14.03 \\
12.89 \\
13.21 \\
10.89 \\
11.04 *\end{array}$ & $\begin{array}{l}3 \cdot 8 \\
3 \cdot 8 \\
3 \cdot 6 \\
3 \cdot 7 \\
4 \cdot 1\end{array}$ \\
\hline & & \multicolumn{3}{|c|}{ Mean \pm SE $12 \cdot 4 I \pm I \cdot 17$} \\
\hline $\left.\begin{array}{l}\mathrm{E}_{2}-\mathrm{R}_{1} \\
\mathrm{E}_{2}-\mathrm{R}_{2} \\
\mathrm{E}_{2}-\mathrm{R}_{3} \\
\mathrm{E}_{2}-\mathrm{R}_{4} \\
\mathrm{E}_{2}-\mathrm{R}_{5}\end{array}\right\}$ & 80 & $\left\{\begin{array}{l}5 \cdot 47 \\
4 \cdot 59 \\
3 \cdot 97 \\
3 \cdot 43 \\
2 \cdot 76\end{array}\right.$ & $\begin{array}{l}14.15 \\
13.09 \\
13.35 \\
12.02 \\
10.71 *\end{array}$ & $\begin{array}{l}3 \cdot 7 \\
3 \cdot 7 \\
3 \cdot 6 \\
3 \cdot 1 \\
3 \cdot 7\end{array}$ \\
\hline & & \multicolumn{3}{|c|}{ Mean $\pm \operatorname{SE} 12.66 \pm 0.52$} \\
\hline $\left.\begin{array}{l}\mathrm{E}_{3}-\mathrm{R}_{\mathrm{I}} \\
\mathrm{E}_{3}-\mathrm{R}_{2} \\
\mathrm{E}_{3}-\mathrm{R}_{3} \\
\mathrm{E}_{3}-\mathrm{R}_{4} \\
\mathrm{E}_{3}-\mathrm{R}_{5}\end{array}\right\}$ & 60 & $\left\{\begin{array}{l}5 \cdot 45 \\
5 \cdot 54 \\
4 \cdot 81 \\
4^{\cdot 66} \\
3^{\cdot 62}\end{array}\right.$ & $\begin{array}{l}\text { I } 5.48 \\
\text { I } 5.92 \\
\text { I } 4.49 \\
\text { I } 3.3 I^{*} \\
\text { I I. } 8 I^{*}\end{array}$ & $\begin{array}{l}3.7 \\
3.7 \\
3.8 \\
3.6 \\
3.8\end{array}$ \\
\hline
\end{tabular}

ME, metabolizable energy.

* Value significantly different $(P<0.05)$ from the value for the corresponding group with the highest riboflavin intake within each energy level.

paralysis ( $\mathrm{P}_{1}-\mathrm{R}_{4}, \mathrm{P}_{1}-\mathrm{R}_{5}, \mathrm{P}_{2}-\mathrm{R}_{4}, \mathrm{P}_{2}-\mathrm{R}_{5}$ and $\mathrm{P}_{3}-\mathrm{R}_{5}$ ) (Table 4) were pooled, those chicks suffering from curled-toe paralysis had a mean percentage count of $45 \cdot \mathrm{I} \pm 2 \cdot 4 \%$ compared with $33 \cdot 0 \pm 2 \cdot 4 \%$ for chicks on the same treatments not showing curled-toe paralysis, a difference that was statistically significant $(P<0.01)$. The mean percentage heterophil count of the chicks given diets adequate in riboflavin $\left(\mathrm{P}_{\mathrm{I}}-\mathrm{R}_{\mathrm{I}}\right.$, $\mathrm{P}_{2}-\mathrm{R}_{\mathrm{I}}$ and $\mathrm{P}_{3}-\mathrm{R}_{1}$, treatments that produced no curled-toe paralysis) was $35^{\circ} 7 \pm 2 \cdot 2$.

Haematocrit values. Pooled values for chicks given riboflavin-deficient diets ( $\mathrm{P}_{\mathrm{I}}-\mathrm{R}_{4}$, $\mathrm{P}_{1}-\mathrm{R}_{5}, \mathrm{P}_{2}-\mathrm{R}_{4}, \mathrm{P}_{2}-\mathrm{R}_{5}$ and $\left.\mathrm{P}_{3}-\mathrm{R}_{5}\right)$ show that there was no difference in mean haematocrit values between the chicks showing curled-toe paralysis $\left(3^{1} \cdot 8 \pm 0.4\right)$ and normal chicks from the same treatment groups $\left(33^{\circ} 0 \pm 0 \cdot 6\right)$. Haematocrit was not influenced noticeably by the level of riboflavin in the diet; chicks given diets $\mathrm{P}_{\mathrm{I}}-\mathrm{RI}_{1}, \mathrm{P}_{2}-\mathrm{RI}_{\mathrm{I}}$ and $\mathrm{P}_{3}-\mathrm{RI}_{\mathrm{I}}$, adequate in riboflavin, had a mean haematocrit value of $3^{1} \cdot 8 \pm 0 \cdot 6$. 
Table 9. Trial 2: effect of riboflavin intake on liver riboflavin content and heterophil counts in chicks

(Mean values for nine chicks/treatment)

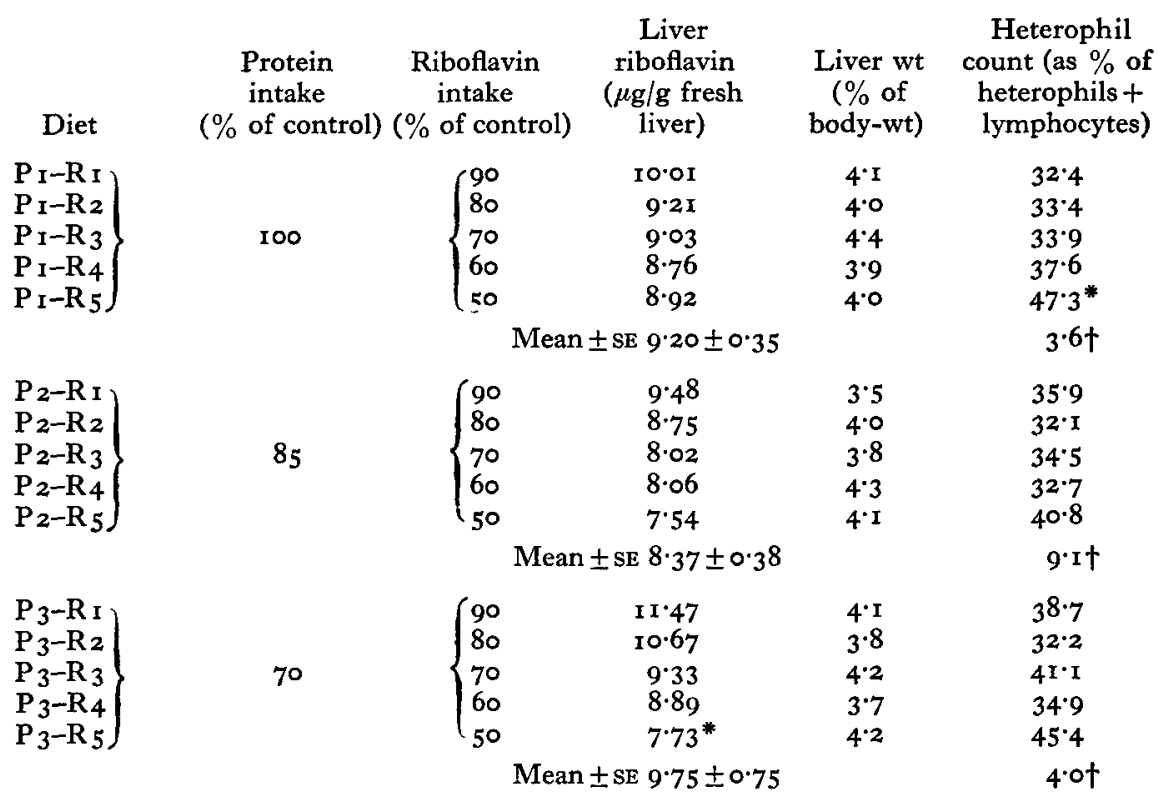

* Value is significantly different $(P<0.05)$ from the value for the group with the highest riboflavin intake within each protein level.

$\uparrow$ Standard error for fifteen observations for each level of protein intake.

\section{DISCUSSION}

\section{The roles of riboflavin in the metabolic pathways}

Riboflavin in animal tissues in the form of one or other of the two coenzymes, flavin-mononucleotide and flavin-adeninedinucleotide, is required for the interrelated biochemical processes involved in the metabolism of carbohydrate, fat and protein.

Studies on the relationships between riboflavin and dietary energy and protein have been made by a number of groups of workers (Sarett et al. I942; Oldham et al. I947; Reiser \& Pearson, 1949; Kaunitz et al. 1954; Chu et al. 1964). However, the chicks were fed $a d l i b$. in these studies, and several important experimental variables, such as riboflavin intake, feed intake (energy, protein, or both), were not well controlled and body composition was not determined. Therefore, (I) riboflavin and other nutrient intakes were dependent upon feed consumption; (2) protein intake was influenced by the energy content of the diet; (3) body-weight as the indicator of growth ignored the difference in body composition of the animals receiving various dietary treatments. In the trials now described methods to standardize energy and protein intake were employed and chemical analysis of carcasses was undertaken. 


\section{Efficiency of fat deposition and protein retention by riboflavin-deficient chicks}

The group of riboflavin-containing enzymes involved in the generation of energy (as ATP) were found by Burch, Lowry, Padilla \& Combs (1956) and Burch, Hunter, Combs \& Schutz (1960) to have priority for the vitamin in a riboflavin deficiency. Therefore, it may be predicted that impairment of the efficiency of energy metabolism would be one of the last signs of deficiency to develop. This was confirmed for, in a severe riboflavin deficiency, when the energy intake of chicks was restricted to varying levels $(80,70$ or $60 \%$ of that of the controls), protein, but not energy, utilization was affected adversely (Table 6 ). When energy intake was restricted to a varying extent from an originally balanced diet (with an optimal energy to protein ratio), relative excess of protein would also have contributed to the inefficient utilization of dietary protein. This was particularly apparent when dietary energy was reduced to $60 \%$ of the control level. Similar observations were made by Kleiber \& Jukes (1942).

However, when the chicks were fed ad lib. on a diet only slightly deficient in riboflavin and permitting rapid growth and generous storage of fat in the body, fat deposition but not protein retention was impaired (Table 5).

These results indicate that the metabolic priorities for energy or protein conservation in riboflavin-deficient chicks differ according to the degree of the deficiency and to whether energy supplies are scarce or abundant. In severe riboflavin deficiency, feed intake of the chicks was drastically reduced, leaving only small amounts of energy and protein above maintenance requirements to provide for growth. Therefore, efficiencies of both dietary energy and protein utilization as measured by carcass analysis were significantly reduced.

\section{Riboflavin-deficiency signs of the chicks}

The results from simultaneous restriction of intakes of energy and protein indicated that with riboflavin deficiency liver riboflavin concentration decreased. This decrease was probably related to low activities of certain enzymes, which in turn might have resulted in certain metabolic disturbances. The heterophilia and high incidence of curled-toe paralysis observed were probably manifestations of these disturbances. These changes occurred before the efficiencies of energy and protein utilization were appreciably reduced. Therefore, it can be concluded that biochemical and haematological changes and the incidence of curled-toe paralysis are more sensitive criteria of riboflavin deficiency than are efficiencies of energy or protein utilization, or weight gain.

\section{REFERENCES}

Appelgate, B. K. \& Potter, L. M. (1963). Feedstuffs, Minneap. 35, no. 43, p. 62.

Association of Official Agricultural Chemists (1960). Official Methods of Analysis 9th ed., p. 669. Washington, DC: Association of Official Agricultural Chemists.

Burch, H. B., Lowry, O. H., Padilla, A. M. \& Combs, A. M. (1956). F. biol. Chem. 223, 29.

Burch, H. B., Hunter, F. E. Jr, Combs, A. M. \& Schutz, B. A. (I960). F. biol. Chem. 235, 1540.

Carew, L. B. Jr \& Hill, F. W. (r964). F. Nutr. 83, 293.

Chu, A. B., Potter, L. M., Appelgate, B. K. \& Leighton, A. T. Jr (I964). Poult. Sci. 43, I307. 
Duncan, D. B. (1955). Biometrics II, I.

Kaunitz, H., Wiesinger, H., Blodi, F. C., Johnson, R. E. \& Slanetz, C. A. (1954). F. Nutr. 52, 467. Kleiber, M. \& Jukes, T. H. (1942). Proc. Soc. exp. Biol. Med. 49, 34.

Mannering, G. J., Lipton, M. A. \& Elvehjem, C. A. (I941). Proc. Soc. exp. Biol. Med. 46, 100.

Oldham, H., Lounds, E. \& Porter, T. (1947). F. Nutr. 34, 69.

Reiser, R. \& Pearson, P. B. (1949). F. Nutr. 38, 247.

Sarett, H. P., Klein, J. R. \& Perlzweig, W. A. (1942). F. Nutr. 24, 295.

Sarett, H. P. \& Perlzweig, W. A. (1943). F. Nutr. 25, i73.

Snedecor, G. W. (1956). Statistical Methods $5^{\text {th }}$ ed., p. 237. Ames, Iowa: Iowa State College Press.

Steel, R. G. \& Torrie, J. H. (1960). Principles and Procedures of Statistics ist ed., p. I58. New York: McGraw-Hill Book Co. Inc. 